\title{
Aa@
}

AUTOBIOGRAFIA nr 2 (5) 2015 s. 125-132

ISSN 2353-8694

DOI: $10.18276 / \mathrm{au} .2015 .2 .5-10$

\section{Auto/biograficzne pęknięcie. Fragmenty dyskusji panelowej „Autobiografia na pograniczu gatunku i doświadczenia".}

ROZMAWIAJĄ:

MAŁGORZATA CZERMIŃSKA, DOROTA KOŁODZIEJCZYK, JERZY MADEJSKI; PROWADZENIE: INGA IWASIÓW

Inga Iwasiów: Ta część konferencji, która odbędzie się w formie debaty, jest związana z jednym z podmiotów współorganizujących dzisiejsze spotkanie. Mam na myśli „Autobiografię”, półrocznik naukowy wychodzący drukiem przy Instytucie Polonistyki i Kulturoznawstwa Uniwersytetu Szczecińskiego. W związku z tym nasza rozmowa przerodzi się - mam taką nadzieję - w rodzaj wywiadu redakcyjnego.

Przechodząc jednak do meritum. Tak się złożyło, że o autobiografizmie rozmawiamy tuż po tym, kiedy Swietłana Aleksijewicz otrzymała Nagrodę Nobla w dziedzinie literatury. Nie byłoby chyba dobrze, gdyby to nazwisko nie padło podczas naszych obrad. To rodzaj pisarstwa, które charakteryzuje się pogranicznością, także w sensie autobiograficznym - o tym właściwie mówiliśmy w wielu momentach tej konferencji. To pogranicze rozszerzające się w „drugą stronę”; nie na „ja” autobiograficzne, ale na inne podmioty. Tę sytuację można by nazwać, no właśnie, może sceną autobiograficzną? Miejscem pisania? Pretekstem do tego, aby wywołać opowieść autobiograficzną?

Chciałabym w związku z tym poprosić, żebyśmy zastanowili się nad autobiografią wywoływaną - jak moglibyśmy jeszcze nazwać ten rodzaj twórczości? - nad tym, na ile ta właśnie rama narracyjna aktywizuje literaturę. To część innej dyskusji, toczącej się po tym ostatnim Noblu: czy mamy do czynienia z reportażem, czy z prozą literacką? Z naszego punktu widzenia chyba ciekawsze jest pytanie o samą sytuację wywołania opowieści autobiograficznej... 
Małgorzata Czermińska: Mam wrażenie, że namysł nad problemem granic literackości w kontekście twórczości Swietłany Aleksijewicz - chyba nie ma sensu. Od dawna pisarstwo typu non-fiction, czyli przede wszystkim autobiografia i reportaż, należy po prostu do świata tekstów. Rozważania genologiczne trzeba w związku z tym zostawić na dalszym planie albo w ogóle z nich zrezygnować.

Natomiast jeśli chodzi o pisarstwo Aleksijewicz, o której rozmowę zaproponowałaś, Ingo, to chciałabym powiedzieć tak: autobiografie przez nią wywołane - szczególnie Cynkowi chłopcy to są teksty per se autobiograficzne. Nawet rzekłabym, że to autobiografie „w pigułce”, chociaż pod pewnymi względami wyróżniają się na tle innych narracji autobiograficznych. Na przykład, mimo głębokich uczuć szacunku i empatii autorki, dostrzec można w jej twórczości reporterskiej nie tylko tragedie wpisane w życiorysy poszczególnych bohaterów, ale także panoramicznie nakreślone tło przedstawianych wydarzeń. Reportaże Aleksijewicz są zawsze skonstruowane wokół konkretnych problemów, choćby wojny afgańskiej w Cynkowych chłopcach czy postkomunizmu w Czasach secondhand. A zatem, powiedziałabym, że problematyzacja społecznego porządku, którym Aleksijewicz się zajmuje, stoi po stronie reportażu. Dla niej wywoływanie autobiografii poszczególnych osób - bohaterów - jest przede wszystkim środkiem, który pozwala na ukazanie problemu nie od strony danych, statystyk, uogólnień, ale ludzkiego przeżycia.

Inga Iwasiów: Jerzy, czy chciałbyś dodać kilka słów do wątku autobiografii wywołanej? Jerzy Madejski: Tak, chociaż ze świadomością, że w ten sposób musiałbym równocześnie nawiązać do „tez programowych” czasopisma „Autobiografia”. Nie jestem jednakowoż przekonany, że na sali znajdują się osoby czytające nasz tytuł... Jeszcze w pełni się nie zadomowiliśmy w środowisku humanistycznym miasta.

Inga Iwasiów: Są wśród nas autorki i autorzy „Autobiografii”...

Jerzy Madejski: ...no tak, chociaż trzeba wziąć pod uwagę, że niekoniecznie czytają całe pismo, a jedynie swoje teksty.

Poważnie mówiąc - jeśli chodzi o tezy programowe i autobiografie wywoływane, to nasze czasopismo konsumuje sytuację społeczną, której byliśmy, poniekąd, sprawcami. Zainteresowanie autobiografią wiąże się z naszymi seminariami doktorskimi i zajęciami, które prowadziliśmy w Gryfińskim Uniwersytecie Trzeciego Wieku. W jakimś sensie podczas tych wyjazdowych zajęć doszło do krystalizacji programu pisma autobiograficznego - i dzisiaj broniłbym go z pełnym przekonaniem. Innymi słowy: potrzebujemy dzisiaj dobrej literatury, która, z jednej strony, jest dla nas wyzwaniem interpretacyjnym, a z drugiej strony - może innym pomóc w organizowaniu własnej pamięć. Tego rodzaju literatura nie powstaje „sama z siebie”, chociaż w trybie eksperymentalnych zajęć warsztatowo-interpretacyjnych można, pisząc takie małe autobiografie, jakieś korzyści z tego dla siebie uzyskać. To zatem pierwszy 
punkt programu „Autobiografii”, do którego jestem jakoś szczególnie przywiązany - to nie tylko pismo akademickie, powołane do życia po to, żeby mogło dawać punkty, ale przede wszystkim przedsięwzięcie intelektualnie osadzone w lokalnych realiach.

Drugi punkt z lokalności poniekąd wynika, ponieważ „Autobiografia” posiada swój wymiar, by tak rzec, praktyczny. To pismo ma na celu nie tylko budowanie teorii współczesnego autobiografizmu, choć to też jedno z założeń naszego programu, może wcale nie najważniejsze. Istotniejszy jest bowiem pragmatyczny wymiar literatury autobiograficznej. Jeśli literatura ma dzisiaj przetrwać - a to przetrwanie wcale nie jest zapewnione - to powinna wyjść poza uniwersytet. Jeżeli mamy uczyć innych o literaturze, to między innymi z nastawieniem praktycznym; tak aby każdy mógł używać literatury dla osobistego pożytku. Powiem wprost: literatura może być narzędziem samorozwoju, i w tym sensie nasze pismo jest mocno związane z wywoływaniem pamięci.

Inga Iwasiów: O piśmie „Autobiografia” może powiemy więcej w dalszej części rozmowy. Chciałabym jednak na chwilę zatrzymać się w orbicie twórczości Aleksijewicz i kategorii autobiografii wywoływanej. Zgadzam się z Małgorzatą, że mówienie o implikacjach czysto gatunkowych ani nie jest w duchu dzisiejszego literaturoznawstwa, ani nie może być jedynym obiektem zainteresowania naszego czasopisma. Natomiast ciekawe wydaje mi się co innego: na czym polega fenomen Aleksijewicz, jeśli uznamy, że to, co ona robi, jest podstawowym narzędziem pracy reporterskiej? Większość reporterów - także polskich - korzysta chętnie z tego narzędzia. Jestem po lekturze większości tekstów Mariusza Szczygła i na pozór on się posługuje tymi samymi metodami pracy dziennikarskiej - próbuje „podstawiać” dyktafon, tematyzuje rozmowy, wprowadza sytuacje, które są ramą modalną wypowiedzi pokazywanych postaci, dopuszcza do głosu bohaterów, ale rezultat jest skrajnie inny... Na czym polegają nadzwyczajność i noblowska klasa Aleksijewicz?

Małgorzata Czermińska: W kontekście tego, o co pytasz, powiedziałabym o dwóch sprawach.

Po pierwsze, kategoria autobiografii wywoływanej ma dość długą tradycję. Konkursy na pamiętniki odbywały się już na początku XX wieku, między innymi za sprawą takich socjologów jak Florian Znaniecki czy Józef Chałasiński. W PRL-u konkursy na pamiętniki dotyczyły choćby przesiedleńców na Ziemiach Zachodnich - chłopów, lekarzy, nauczycieli i tak dalej. Nie twierdzę oczywiście, że Aleksijewicz musiała się z tymi wszystkimi tekstami zapoznać, żeby wymyślić własną metodę opowiadania o przeszłości. Chodzi mi raczej o to, że my - jako czytelnicy - powinniśmy sobie uprzytomnić, że tkwimy w pewnej tradycji. To jest szalenie ważne - mieć poczucie ciągłości wtedy, kiedy świat się zmienia. Siłę, wartość i kierunek tych zmian możemy przeżyć i zrozumieć dopiero wtedy, gdy widzimy ten sensowny ciąg wydarzeń, tę tradycję. 
Po drugie, czy można przyznać literackiego Nobla za pracę reporterską? Można - i lektura tekstów Aleksijewicz przekonuje mnie o trafności tego wyboru. Tym, co charakteryzuje jej twórczość, na tle pracy innych reporterów, jest moim zdaniem rola słuchaczki, w którą wciela się autorka. Aleksijewicz powiedziała gdzieś, że pracuje „uchem”. Słucha swoich bohaterów. Widać, a może raczej - słychać to wyraźnie w Cynkowych chłopcach, gdzie pozostały ślady dialogów, które reporterka prowadziła ze swoimi rozmówcami. Ona jest tam ukryta jako słuchaczka, bohaterowie przecież mówią przede wszystkim do niej. W tym sensie te wywoływane autobiografie się ze sobą krzyżują, przecinają, zbiegają, ale w jej doświadczeniu; bo przecież ci ludzie, opowiadający swoje historie, nie znali się. To reporterka jest w centrum, skupia ich uwagę. Autobiografie „przechodzą” przez nią, stają się częścią jej życia. Mówi przecież podczas procesu do jednej z matek, że razem z nią płakała. Albo wspomina, iż podczas pobytu w Afganistanie - w miejscu, gdzie granaty rozerwały ludzi na strzępy - zemdlała. To są jej własne, głębokie, fizjologiczne przeżycia - i one są jakoś jednak w tych tekstach uchwytne, natomiast w żadnym razie nie przytłumiają głosów tych, w których imieniu ona mówi.

Co do Mariusza Szczygła - zgadzam się, chociaż można by przywołać też twórczość Ryszarda Kapuścińskiego. Cynkowi chłopcy najbardziej przypominają Cesarza, może nie w sensie bezpośredniej inspiracji, ale na pewno analogii. W Cesarzu również jest ogromna sekwencja monologów, nie nagrywanych raczej, ale wyreżyserowanych. Udział reportera w kreowaniu czy wywoływaniu autobiografii był zatem znaczący. Podobieństwo polega na umiejętności słuchania - Kapuściński, zwłaszcza w tej książce, wysłuchiwał tych wszystkich afrykańskich opowieści, przenoszonych z pokolenia na pokolenie, szukał ich u swoich bohaterów, ponieważ poniekąd też chciał być takim opowiadaczem.

Aleksijewicz, na swój sposób, jest i słuchaczką opowieści świata, i przekaźnikiem wysłuchanych historii.

Inga Iwasiów: Przyszło mi do głowy jeszcze inne porównanie, mianowicie do postawy pisarskiej Hanny Krall. Przy czym u Kapuścińskiego figura słuchania przekazywana jest „pod spodem”, u Krall - „na wierzchu”.

Jerzy Madejski: Ta różnica na linii Kapuściński - Krall wiąże się z jeszcze innym przesunięciem. Inaczej oboje traktują „źródło”. Kapuściński szuka opowiadacza, który swoim własnym głosem ma oddać egzotykę, a Krall - oddaje głos opowiadaczom. My dzisiaj przede wszystkim potrzebujemy głosu świadka, dającego nam poczucie obcowania z przeżywanymi światami. Takiego głosu udziela swoim bohaterom Aleksijewicz.

Inga Iwasiów: U autorki Cynkowych chłopców i wielu innych poruszających książek reporterskich „oddać głos” wprost oznacza oddanie głosu, bez cudzysłowu. Właśnie, chciałabym zapytać Ciebie, Doroto, o wątek postkolonialny, o analogię do „oddawania” czy „udzielania” głosu. Jaka jest pozycja podmiotów słabych wobec reportera-narratora? 
Dorota Kołodziejczyk: Wracając do kwestii genologicznej - nie możemy całkowicie porzucić rozważań nad gatunkiem. Czy mamy prawo, na przykład, mówić o autobiografizmie w poezji albo w prozatorskich utworach fikcjonalnych? To pytanie nierzadko powracające w dyskusjach o autobiografii, która jest międzygatunkowa, a przy tym związana z teorią postkolonialną. Czy z punktu widzenia postkolonializmu jest różnica między opowieścią autobiograficzną a świadectwem? W moim odczuciu świadectwo to mniej scalający rodzaj opowieści niż autobiografia - celem autobiografii jest chyba jednak właśnie scalanie, a świadectwo występuje w odniesieniu do specyficznych wydarzeń. Autobiografia to znacznie szersze pojęcie.

Dlatego w postkolonialnych kontekstach tego typu narracje - jak choćby dyskutowana tu przez nas proza Aleksijewicz - są raczej czymś w rodzaju świadectwa, ale w szerszym polu, które można określić mianem life writing.

Przechodząc do kwestii głosu - to ważny problem dla powiązania reportażu i teorii postkolonialnej. Bo musielibyśmy postawić pytanie, czy na przykład samo wywoływanie głosu nie jest przypadkiem - niezamierzoną, ale nieuchronną - oznaką zawłaszczania życia tego, kto opowiada? W tekstach Hanny Krall, mimo postulatu oddawania głosu bohaterom, można uchwycić dość wyraźną grę z zawłaszczaniem głosu. Nie każde świadectwo i nie każda opowieść ją interesują. Ona oczekuje, że to, co będzie opowiadane, okaże się interesujące, a robi to, jak mniemam, w imię etyki zawodu dziennikarskiego.

Inga Iwasiów: Zastanawiam się, na ile nad polską szkołą reportażu unosi się jednak przekonanie o tym, że - z jednej strony - reporter ma powinności wobec dostarczyciela świadectwa, a z drugiej strony - jednak wartością nadrzędną reportażu jest artyzm. Dlatego wycofanie podmiotu z samego tekstu oznaczałoby wycofanie władzy nad opowieścią. Artyzm może być ironią - i to jest najczęstsza cecha pogranicznych, reportersko-literackich relacji, charakterystycznych dla współczesnego polskiego reportażu. W wypadku twórczości Aleksijewicz radykalne wycofanie reporterki, przekazującej historie innych ludzi, oznacza też wycofanie się z artystycznych ambicji. W polskich reportażach najnowszych mamy do czynienia z dziwnym splotem empatii i ironii. Czy z reportaży Aleksijewicz wydzielić można jeszcze jakąś inną cechę, odróżniającą ją od polskich twórców? Prowizorycznie powiedziałabym, że taką kategorią - poza dużym zamiarem opisania historii - może być empatia, ale pozbawiona tego rysu ironicznego.

Małgorzata Czermińska: Chciałabym w co najmniej dwóch istotnych sprawach nie zgodzić się z Dorotą.

Otóż, po pierwsze, dyskusja nad gatunkiem, jak mówiłam na wstępie, wydaje mi się mimo wszystko wyczerpana. Kategoriami genologicznymi możemy posługiwać się jedynie przy interpretacji poszczególnych tekstów, żeby osadzić je w konkretnej tradycji. Z kolei nadużywanie kategorii autobiografii też nie przynosi pożytku, ponieważ zaciera granice autorstwa. 
Każdy tekst, w jakimś sensie, wyraża swojego autora, ale nie każdy przecież musi być autobiografią. Trzeba jednak postawić jakąś „granicę” i nie wchodzić w kłótnie wokół tematu niech to będzie przykład - czy autobiografia może być pisana wierszem, ponieważ według Philippe’a Lejeune’a autobiograficzny jest tylko tekst pisany prozą. To dzisiaj, moim zdaniem, jałowa gleba.

Wyjściem z tego impasu powinno być wprowadzenie kategorii nieesencjalnej. Autobiografia to nie forma, gatunek, tekst... „Żywioł” autobiograficzny? „Tło” autobiograficzne? Czy też - by odwołać się do starszych kategorii - „postawa” autobiograficzna?

Wróćmy jednak do Aleksijewicz: czy ona, wywołując autobiografie, zachowuje empatię wobec swoich rozmówców - bohaterów? I to jest druga sprawa, co do której muszę się z Dorotą nie zgodzić. W szacunku dla innej osoby - w delikatności, której uczy nas teoria postkolonialna - też nie można popadać w przesadę. Reporter powinien przecież podejmować ryzyko! Może dotknie? A czasem i urazi...? Aleksijewicz podejmuje to ryzyko na każdym kroku, kiedy rozmawia z bohaterami o ich najbardziej przecież traumatycznych przeżyciach. Gdyby myślała tylko z punku widzenia swojej empatii, to nie spotkałaby się, dosłownie, z tymi ludźmi, dzielącymi się z nią najgłębiej skrywanymi bolesnymi przeżyciami. Niektórzy z nich się denerwują, płaczą, krzyczą na nią - co nie znaczy, że reporterka próbowała nimi „zawładnąć”. Raczej po prostu dała im się wypowiedzieć, dotknęła tego, co jest ważne, wywołała emocje.

Jak Aleksijewicz organizuje swoje opowieści? W Cynkowych chłopcach zapisała pewien typ autobiografii - „autobiografię z przełomem”. To są historie ludzi posiadających dwie osobowości, dwie biografie, w pewnym momencie rozpęknięte. Przed wojną afgańską i po tym, co się tam stało. To jest koncepcja znana co najmniej od czasów świętego Augustyna - radykalny rozpad na to, co było „przed”, i na to, co nastąpiło „po”. To klasyczny model „autobiografii z przełomem”. Z tym mamy do czynienia w Cynkowych chłopcach - to autobiografie ludzi „pękniętych”. I dlatego tą książką Aleksijewicz musi zranić. Może też zranić swoich bohaterów. I naszym obowiązkiem - jako czytelników - jest przejąć się tymi opowieściami. Dorota Kołodziejczyk: Wrócę do kwestii zawłaszczenia, bo wydaje mi się, że w naszej dyskusji „zawłaszczony” został pewien termin. Miałam na myśli coś innego - chodziło mi o formułę zawłaszczenia wpisaną w format reportażu lub innej autobiografii wywołanej. Zawłaszczenie nie musi być faktem - raczej jest podejmowanym świadomie ryzykiem. Dziennikarz zdaje sobie sprawę, że może coś lub kogoś, czyjąś opowieść, zawłaszczyć. I w ramach procesu dialogowego, opowiadania/słuchania, ma miejsce walka z siłami zawłaszczającymi opowieść i osobę opowiadającego. 
Prawdziwe ukazanie głosu jest możliwe tylko wtedy, gdy ktoś ten głos sobie „bierze”. Najciekawsze są momenty, kiedy tenże głos jest „wzięty z zaskoczenia”. Natomiast gest oddawania głosu jest zawsze w jakimś sensie kolonialny.

Małgorzata Czermińska: Czy sądzisz, że problem zawłaszczania/uwalniania czyjegoś głosu staje się ważny wtedy, gdy mamy do czynienia z formą biografii czy autobiografii wywołanej? Prawdziwa autonomia jest wtedy, gdy ktoś sam zabiera głos - właśnie mi to uświadomiłaś! Co innego odpowiedzieć na apel, a co innego - zabrać głos samemu, czyli napisać autobiografię przez nikogo nie wywoływaną.

Dorota Kołodziejczyk: Mimo wszystko gest wywoływania/zawłaszczania jest bardzo ważny inaczej nie poznalibyśmy tych biografii, o których opowiadają, na przykład, bohaterowie Aleksijewicz. Czy lepiej zaryzykować zawłaszczanie, czy nie poznać wywołanej opowieści autobiograficznej?

Inga Iwasiów: Skomentuję krótko zagadnienie wcześniej poruszone przez Małgorzatę. Wydaje się - w związku z tym, co powiedziałaś - że wartościowe mogą być tylko te autobiografie, których źródło wypływa z życiowych dramatów. Są one w opozycji do wieloletniego przekonania, że o życiu, jako takim, najwięcej w literaturze mówią nam nuda, monotonia i codzienność. Jak w dzienniku terapii alkoholika - to jest nudne, choć może zamienić się w opowieść dzielącą doświadczenie na dwie części. Na życie „przed” piciem i życie „po” piciu. To „w środku” nie jest atrakcyjne.

Jerzy Madejski: Z tego, co mówisz, Ingo, wyłania się raczej program czasopisma „Reportaż”, a nie „Autobiografii”...

Łagodnie nie zgodziłbym się natomiast z tym, co powiedziała chwilę wcześniej Małgorzata Czermińska. Potrzeba nam bowiem dzisiaj ogarniania skomplikowanej sieci tekstów, które mają w sobie coś autobiograficznego. Znajdujemy się w punkcie krytycznym - jest wiele praktyk autobiograficznych wymagających „do-czytania”. Co to jest relacja z terapii alkoholowej? Jaką ma logikę relacja z nawrócenia? To mniej więcej wiemy. Idąc dalej, potrzebujemy teorii biografii: sportowców, piosenkarzy, polityków i tak dalej. Jeszcze inny problem to ghostwriting, „zastępstwo w pisaniu”, współautorstwo - trzeba te zagadnienia teoretycznie zagospodarować. Miałbym apetyt na więcej.

Uważam, że pewna odmiana autobiografii profesjonalnej pełni nie tylko funkcję estetyczną, ale przede wszystkim - krytyczną. Mam na myśli choćby autobiografię Andrzeja Mencwela. Pisze ją ktoś, kto ma do dyspozycji narzędzia teoretyczne, antropologiczne, krytyczne, i może je zaangażować do opisu społeczności lokalnej. Sprawdza „w działaniu” fundamenty swoich teorii, ale bez akademickiego nacisku, bez konieczności ubiegania się o granty i przymus zdobywania punktów. 
Powiedziałbym tak: potrzeba nam więcej autobiografii. Znacznie więcej autobiograficznych postaw, wyznań i świadectw. Kiedyś w gazetach pojawiało się hasło: „Proletariusze wszystkich krajów, łączcie się!”. Dzisiaj zamieniłbym je na: „Każdy ma prawo do autobiografii”.

Dyskusja stanowiła jeden z punktów programu Międzynarodowej Konferencji Naukowej „Autobiografie (po) graniczne”. Konferencja, zorganizowana przez Centrum Badań Dyskursów Postzależnościowych Uniwersytetu Warszawskiego oraz Instytut Polonistyki i Kulturoznawstwa Uniwersytetu Szczecińskiego, odbyła się w dniach 15-17 października 2015 roku w Szczecinie.

Spisał i opracował Sławomir Iwasiów

\section{PROSIMY O CYTOWANIE TEGO ARTYKUŁU JAKO:}

Auto/biograficzne pęknięcie. Fragmenty dyskusji panelowej „Autobiografia na pograniczu gatunku i doświadczenia". Rozmawiają: Małgorzata Czermińska, Dorota Kołodziejczyk, Jerzy Madejski; prowadzenie: Inga Iwasiów, „Autobiografia. Literatura. Kultura. Media” 2015, nr 2 (5), s. 125-132. 